\title{
The Spectacle of Guns and Hope
}

\author{
RAFAEL MARQUES DE MORAIS \\ MakaAngola
}

The Arab Spring sparkled throughout the Middle East. In Angola, a small group of youngsters tried to emulate it by holding symbolic anti-government protests to end the rule of then President Dos Santos. Their motto was '32 is too much!'.

On 2 April 2011, for the first time the government refrained from squashing a protest in Luanda. The police cordoned off the area and peacefully let the small group chant and insult the president for several hours. That is when, what would become the anthem of protests was first sang: 'Primeiro os angolanos, segundo os angolanos, terceiro os angolanos, angolanos sempre!' (First Angolans, second Angolans, third Angolans, Angolans forever!).

Ironically, this was one of Jonas Savimbi's most memorable rally slogans in the 1992 first democratic elections ever held in Angola. I chose the picture of the poster with such a campaign slogan 'Primeiro os angolanos, Angolanos sempre!', to reflect on that year of great and shattered hopes for the country.

Within weeks of beginning my professional career, at the only daily newspaper in the country to date, the Jornal de Angola, I was assigned to cover simultaneously the implementation of the peace and electoral processes. Both parties were equally betting on guns and ballots. There was only a sixteen months' time frame between the signing of the peace agreement, after sixteen years of war, and the holding of elections.

There was the spell of peace, hope and simmering tension. Public fervor for democracy and change had equal measure in the public sentiment of fear and for retribution.

As the political and military tensions kept escalating, the United Nations, the mediator of the peace process, and of the Troika of Observers (Russia, United States of America and Portugal) deployed their best political and sometimes nonsensical rhetoric that peace and democracy were on track.

In the newsroom of the Jornal de Angola, I found myself in a surreal world. On my desk, next to the typewriter, there was a bulky and sealed green-olive metal box of ammunitions. They were bullets for the machine gun set by the window. In the basement of the newspaper, the canteen had been turned into a makeshift hideout and sleeping quarters for the fearsome 'Ninjas', the Angolan commandos trained in Spain as special police forces. This military outfit eluded the oversight of the joint commission.

Down the road, a block away from the Jornal de Angola, there was Hotel Turismo, where UNITA leaders, their families and dozens of their bodyguards had been housed. In between, on the other side of the road, there was the provincial Command 
of the Police and the headquarters of the navy. UNITA had deployed its own arsenal of tricks to keep its military forces intact. However, in Luanda it could do little more than put on a roadshow of fearsome commandos roaming the streets at the back of pick-up trucks, wearing grenade-filled vests and slinging two weapons each, usually a Kalashnikov and a grenade launcher.

How could there be peace and free and fair elections under those circumstances? I had that question definitely answered when I witnessed the distribution of Kalashnikovs, by the tens of thousands, in the capital. A Portuguese friend, a poet who managed a bookstore, and mentored me on poetry and literature in general, had received crates of weapons in his house. That house was a treasured library, worshiped by young and aspiring poets. Yet, this foreign poet was proud to be distributing guns to his neighbours at the behest of the ruling MPLA's side. The only requirement was the will to kill the enemy, soon to be declared as such again.

While Savimbi was hiding his guerrillas and weapons somewhere in the bush, the MPLA was building an army of civilians and demobilised soldiers in plain sight in Luanda. The whole UNITA leadership was in Luanda under the peace process and thus trapped.

But guns were not the biggest problem. It was propaganda. It was the weaponised media, which had the broadcasting power to set the mood for war and the narrative of which side would be the culprit.

Then came the electoral results in which the ruling MPLA claimed victory, and Dos Santos and Savimbi had to square off in a second round. Contrary to common belief, Savimbi did not refuse the elections results. This lie became the international community's narrative to justify how badly the United Nations and the Troika mishandled the peace process in Angola, and for ultimately taking the side that was convenient.

The Jornal de Angola, the government's mouthpiece I worked for, published, on 17 October 1992, two clear headlines. The main one 'Vamos ter segunda volta' (We will have a second turn) reported on the final election's results of 29 and 30 September of that same year. José Eduardo dos Santos had 49,57\% of the votes, while Savimbi had clinched $40,07 \%$ of the votes in the presidential poll. Meanwhile, Dos Santos' MPLA won the legislative elections with $53,74 \%$ and Savimbi's UNITA trailed far behind with $34,10 \%$ of the votes.

The second headline, beneath the abovementioned, 'Savimbi diz que aceita resultados como estão', is clear: 'Savimbi decided to accept the elections' results as they are right now' to overcome the ongoing stalemate in the country and avoid the return to war.

To make his statement as clear as possible, Savimbi held a joint press conference with the leaders of six other opposition parties, who had also accused the MPLA government of vote rigging, to express a unified acceptance of the electoral results.

Letters were sent to the United Nations to confirm that acceptance. Yet, several UNITA generals and rank and file, who had joined the single Angolan Armed Forces (FAA), under the peace process, had returned to UNITA. This movement started taking 
over towns. One of them, was the diamond rich Cuango where I had been just a few days before

War, it seemed, was inevitable.

I had first-hand experience of the unfolding events in Luanda. On 31 October, a Saturday, the Jornal de Angola sent me to cover an emergency meeting at the Joint Commission.

The streets were nearly deserted. All was set for fighting in Luanda, and the UNITA leadership had no way out of the capital. There were only three journalists to cover the meeting: Luísa Rogério, then a senior reporter at Jornal de Angola, our photographer Paulino Damião and myself.

The late General Cirilo de Sá 'Ita', and the late General Arlindo Chenda Pena 'Ben-Ben' were trading barbs in the street right in front of CCPM office. Both were in the single army, with the first coming from the government forces and the second from UNITA forces. Nonchalant and smiling, General Ita warned his colleague that the civilians and the criminals armed by MPLA would wipe out UNITA in Luanda without the need for the army's involvement. General Ben-Ben, visibly nervous, replied that UNITA commandos would bring hell to Luanda, and the whole country would be destroyed.

How could war, which Angolans had already endured for a total of 30 years (including the 14 year war for the struggle for independence) fit into the slogan 'Angolans first, Angolans forever?' It was a civil war for Angolans to kill one another for the sake of power.

Paulino Damião and I did not make it inside the building. We remained outside. As the UNITA chief negotiator, the late Salupeto Pena, left the building in a convoy with commandos with their guns at ready by the windows, we followed behind on foot. They were driving so slowly that we could follow. They were going to Hotel Turismo on the same road to the Jornal de Angola. There was not much thought about the idea of following the convoy. We just needed to get the hell out of there and try to get as close as possible to the Jornal de Angola, which was less than a kilometer and a half from the Joint Commission. We managed to walk two thirds of the distance, and fire broke out. It would take us three nights to reach the paper.

In front of us there was a man in the middle of the road, holding a machine gun. When the UNITA convoy passed by him, right by the Ministry of Finance, I hit my colleague on the back of his neck, and instinctively threw him on the ground with myself following suit. Before he could complain, the machine gun was spitting fire tracing bullets - towards us.

After a few minutes, we had to move because we were too exposed, particularly to sniper fire and those civilians who might not be able to distinguish enemies from innocent civilians.

We could not cross the square to reach the paper. We entered a building and followed a resident to his apartment. He turned out to be an off-duty government commando. His elder brother, the owner of the apartment, was a police officer. We had an initial sense of relief. However, it was a one bedroom apartment and from the glassed 
living room we could see the UNITA provincial delegation, which was the site of a fierce battle. That sense of relief quickly turned into worries.

In war one sees the best and worst of human kind in such extreme ways, and the time we make to carry on with what seem trivial issues. Soon, my colleague learned that our hosts were from the south, UNITA's stronghold, and that the police officer did not seem pro-government, and whispered to me that we had to get out of there.

Fortunately, I had only seen the kindness of the police officer who offered us food. I thanked him and told him I was a vegetarian, and could eat neither meat nor fish. He stepped out of the apartment, and soon returned with some canned beans for me. How could I concern myself with the ethnic background or political standing of this man? I whispered back to say I was staying, and grateful for our hosts' kindness. My colleague obliged, and retracted for letting his fear cloud his judgement.

The following day, while the killings were still going on, we decided to sit at the end of the corridor overlooking the Mutamba square, between the Ministry of Finance and the provincial government's headquarters. We chatted with our newlyfound friend the commando. One floor above us, a young man who was in the same position as us, was shot by a sniper.

But our nightmare was yet to come when we finally decided that the shooting had subsided and we had to make it back to the paper. The commando accompanied us out of the building to help us cross the street safely to the Ministry of Finance where we could seek help from police.

As we were about to cross the road, a well known owner of a night club, behind the newspaper, shouted to a rather tall and muscled special police force, who had cut the front of his boots to let his toes out, that we were stray UNITA officers and to shoot us.

The 'ninja' took aim at us, and with our hands up we shouted back that we were journalists from the Jornal de Angola - Paulino Damião had his camera visible. But we had a problem. The commando refused to put his arms up. The 'ninja' shouted that he would count until ten for us to reach him with our hands up otherwise he would shoot.

For our lives we begged the comando to cross the road with us, and so he did. The police officer confirmed our identities, and we vouched for the commando, who had no papers with him, that he had saved our lives. Ironically, as we were chatting, another civilian got caught and brought to the 'ninja'. This countryman had no papers but only money from Ivory Coast. We all looked at each other and right away identified him as a member of UNITA. The 'ninja' told all of us how lucky we were because he had already killed too many people, and thus he would let the suspected UNITA member live. He even wished him good luck, if he managed to survive or avoid capture in the next three blocks.

Back in the newspaper, I was the only journalist. The chief editor showed up a bit later and assigned me to go to the police and cover the mop up operations. I witnessed the surrender of the surviving UNITA officials and their relatives at Hotel Turismo. 
With two British journalists we went to see the clearing of Savimbi's house, the streets strewn with dead bodies. In São Paulo, I had another episode of some foul mouth shouting for us to be killed as UNITA and the 'whites who ran away from Savimbi's house?

I was at the back of an old and open yellow Willys Jeep. I stood up shouting back 'we are from Jornal de Angola!' Some of the militias came to check, and confirmed my identity, but then said the foreign journalists had to be killed so as not to report what they had seen. I argued that they were consultants for Jornal de Angola, upon which they went to call their leader to confirm whether it was true or not. They threatened to shoot me as well if I was lying.

Unbelievably, the head of the militias was a senior director at the Jornal de Angola. He was holding his AK and had a belt of bullets crossing his chest. He just said 'he is my kid, and the whites are with us. That is what saved us and enabled the British journalists to have access to the room were they had piled up tens of people and burned them all.

I then went to the provincial police command, five minutes walk from Jornal de Angola. There I saw the bodies of Salupeto Pena and UNITA's vice-president being kicked in the pátio. While I sat on a bench by the commander's office door, waiting to speak to him, next to me sat one of the opposition leader's, Nfulumpinga Landu Victor. Each passing police officer would kick, slap or punch him at will, and many passed. Sometimes I had to jump to avoid being hit. He had supported UNITA.

Years later, while in London, I bought Blood on the Tracks by Miles Bredin. He was the Times reporter with me that day. He, who did not even dare to open his mouth, noted my sangfroid in that situation, but claimed to have talked his way out of the situation. It really infuriated me.

This was 1992, the year in which Angolans renewed, as their priority, the killing of one another. The slogan 'Angolans first, Angolans forever' made no sense, in this reality of killing fields. As the young protesters adopted such a slogan as their anthem, it made no sense too. Those were the years of untrammeled plundering of the country. Now with Savimbi gone, and Dos Santos self-exiled in Barcelona, there is hope that Angolans may forge a more humane society, where the value of life and human dignity will be the centerpiece of 'Angolans first, Angolans forever'. 